NBER WORKING PAPER SERIES

\title{
HAS WORK-SHARING WORKED IN GERMANY?
}

Jennifer Hunt

Working Paper 5724

\section{NATIONAL BUREAU OF ECONOMIC RESEARCH 1050 Massachusetts Avenue \\ Cambridge, MA 02138 \\ August 1996}

I thank Alison Booth, Ed Lazear, Dan Hamermesh, Michael Lechner, John Pencavel, Joel Waldfogel and seminar participants at Stanford and the ZEW (Mannheim) for suggestions. Reinhard Bispinck provided me with essential information, and Tomas Rauberger was invaluable in setting up the GSOEP data. This research was conducted while I was a National Fellow at the Hoover Institution. This paper is part of NBER's research program in Labor Studies. Any opinions expressed are those of the author and not those of the National Bureau of Economic Research.

(C) 1996 by Jennifer Hunt. All rights reserved. Short sections of text, not to exceed two paragraphs, may be quoted without explicit permission provided that full credit, including (C) notice, is given to the source. 
"About one third of the 3.2 million person increase in employment between 1983 and 1992 can be attributed to the reduction in working hours. "

"The average standard yearly working time in the Federal Republic was [...] 1669.7 hours in 1994. An employment-oriented reduction and flexibilization of standard working hours must aim to reduce this to [...] 1350 hours by 2005 .

German government employment reports (Senatsvervaltung für Arbeit und Frauen 1995a,b)

There is a wide-spread popular belief that unemployment can be reduced by reducing the number of hours worked per person. The reasoning is usually based on what is sometimes called the "lump of work fallacy": labor input is seen as fixed, and it is believed that if each worker works fewer hours, this work can be spread over more workers, and employment will rise. This is known as work-sharing. However, if restrictions on hours make labor less attractive to employers, they will substitute to other inputs, and there will also be a scale effect reducing use of all inputs.

Interest in work-sharing resurfaces periodically in different countries, and has been particularly high in Europe in recent years, following the rise in unemployment since the mid-1970s. The tool of choice in Europe for the reduction of working hours is a reduction in the standard work week: that is, a reduction in the number of hours beyond which an overtime premium must be paid. The French and Belgian governments mandated reductions in the standard work week in the 1980s, while German unions have achieved more far-reaching reductions on an industry by industry basis. In 1996 the French government is threatening to reduce standard hours further from the current 39 if employers and unions do not agree amongst themselves to do so. In the United States mandated overtime premia have been preferred as an inducement to work-sharing (the $50 \%$ premium is higher than typical premia in Europe), but the 
AFL-CIO in 1996 began a campaign for a 32-hour 4-day work week. The use of standard hours as an hours-reducing tool introduces further ambiguity into the theoretical problem, however, since employers have the option of shifting to using more overtime.

Most studies of reductions in standard hours have relied on aggregate time series, where the effect of falling standard hours could be confounded with the effect of another variable trending down. In this paper I take advantage of the industry level variation in standard hours reductions in (West) Germany to identify the impact on employment, focusing particularly on the 1980s. The reductions began with the metal-working and printing sectors in 1985, where standard hours fell in steps from 40 to 37 between 1984 and 1989. Most other sectors had a smaller reduction beginning later, while some sectors had no reductions in this period.

Only one econometric study of this episode has been carried out, a study using aggregate time-series. I use data on 201 manufacturing industries to look at employment directly, and individual-level data on all industries from the German Socio-Economic Panel to examine layoff probabilities. Employer-initiated changes in employment stem from changes in hiring or layoff rates, so at least one part of the process may be examined at a micro-level (hiring rates are harder to study with individual data).

My results provide a less positive assessment of work-sharing than most of the existing literature. Industry and individual level data indicate that employment increased by $0.3-0.7 \%$ for hourly workers (Arbeiter) and by $0.2-0.3 \%$ for salaried workers (Angestellten) in response to a one hour fall in standard hours. However, the implied aggregate employment rise of at most $1.1 \%$ from 1984-89 is small compared with the U.S. employment growth over the same period (7.3\% growth in the employment to population ratio), which is arguably the target for 
the slower German employment growth (3.2\% growth in the employment to population ratio). Furthermore, reductions in standard hours led to large falls in total hours worked, and hence possibly output losses: a one hour reduction in standard hours was associated with a $2-3 \%$ fall in worker-hours for hourly-paid workers. Workers as a whole did appear to gain from the hours reductions, however, as the wage bill rose for both hourly-paid and salaried workers. The first phase of work-sharing thus apparently worked in the sense that employment rose and workers as a group gained in terms of income and leisure. But employment did not rise enough to redress Germany's employment growth problem, and the large falls in worker-hours suggest that output losses may have occurred. Results for the $1990-94$ period are more pessimistic.

\section{Hours Reductions in Germany}

Unions in Germany bargain at the industry level, and conditions of union contracts apply not only to members, but to almost all other workers as well. Annual hours may be reduced either by increasing holiday time or by reducing standard weekly hours. By 1975 the prevailing conditions were 40 hours per week and 30 days annual leave, and by $198195 \%$ of workers had a standard working week of 40 hours $^{1}$. The metal workers' union, IG Metall, which along with the printing union IG Druck had spearheaded earlier reductions in weekly hours, struck unsuccessfully in 1978-9 to reduce standard weekly hours below 40 . Other unions, such as IG Chemie, the chemical union, focused on reducing life-time hours by reducing the retirement age. IG Metall resumed its demands in 1982-3, and was successful after a protracted strike in early 1984. The declared aim of the hours reductions was a reduction in unemployment through 
work-sharing. Hours in the metal-working sector (employing almost four million workers) were reduced to 38.5 in 1985 .

A key element of the agreement, upon which agreements in many other sectors were modelled, was the concession to employers of greater flexibility in the use of standard hours. In particular, standard hours no longer had to be spread evenly over each day of the week, and could in fact vary from week to week as long as they averaged to the agreed number over a certain number of months. ${ }^{2}$ Also, standard hours could vary across employees as long as they averaged to the agreed number. It is important to note that the implementation of flexibility is a matter to be negotiated at the plant level between the management and the works council, and surveys have found that the majority of plants, particularly small plants, have not taken advantage of the flexibility provisions (Bosch et. al. 1988).

A further issue to be resolved by management and works councils is the method of implementation of the reduced standard week. Some firms reduced hours on Thursdays and Fridays, some reduced the hours of each weekday by an equal amount, while others reduced hours by awarding workers days off. Bosch (1990) reports that, initially, capital-intensive industries preferred days off, while labor intensive industries reduced weekly or daily hours. As the standard work week fell further, however, the number of days off to be allocated became too great to be efficient, and the move to a reduction in daily hours (or a mixture of reduction in hours and days off) became more generalized.

Finally, certain union agreements recommended caps on overtime (or the compensation of some overtime with days off) to prevent the substitution of overtime hours for standard hours. 
This is again something to be implemented at the plant level by the works council and management, and is obviously potentially important for work-sharing.

The agreement in the metal-working sector and the simultaneous agreement in the printing sector were followed by more and more manufacturing and service industries over the subsequent years. IG Metall itself in two later agreements negotiated further step-wise reductions in standard hours, which have recently culminated (October 1995) in the 35-hour week. IG Metall has announced that it seeks further reductions. Average standard hours worked fell from 40.0 in 1984 to 38.8 in 1989 to 37.7 in 1994 (IAB 1995). In 1990 actual annual hours per worker were $10 \%$ lower in Germany than in the U.S. (Bell and Freeman 1995). ${ }^{3}$

The agreements reached concerning standard hours often extend over a period of several years, involving step-wise falls in hours, while wages typically continue to be renegotiated each year. In most cases the unions announced that they had achieved their aim of "full wage compensation", meaning that weekly or monthly earnings (without overtime) were not reduced despite the hours reductions (which implies a rise in the hourly straight-time wage). Hunt (1996) finds that in the period 1984-89 this did in fact occur, so that monthly pay for workers working the standard week did not fall in industries with standard hours reductions, relative to other industries. 


\section{Theory}

Consider a firm taking standard hours $\left(\mathrm{h}_{\mathrm{s}}\right)$, hourly wages $(\mathrm{w})$ and the rental rate of capital (r) as given, and choosing actual hours per worker (h), employment $(\mathrm{N})$ and capital $(\mathrm{K})$ in the presence of fixed costs of employment (f), and an overtime premium (p):

$$
\max _{h_{,}, K, K} g(h, N, K)-w h N-f N-p w\left(h-h_{s}\right) N-r K
$$

Assume that this firm chooses non-zero overtime hours $\left(h>h_{s}\right)$, due to a high fixed cost of employment $\mathrm{f}$. Consider now an exogenous reduction in standard hours, which due to the overtime premium increases labor costs. There will be a scale effect, tending to reduce employment and hours per week, and a substitution effect from labor services to capital. Worker-hours thus fall unambiguously. Substitution between hours per worker and workers is made clearer by considering the marginal cost of hiring an additional worker $\left(\mathrm{MC}_{\mathrm{N}}\right)$ and the marginal cost of an additional hour's work by existing workers $\left(\mathrm{MC}_{\mathrm{h}}\right)$ :

$$
\begin{aligned}
M C_{N} & =w h+f+p w\left(h-h_{s}\right) \\
M C_{h} & =(1+p) w N
\end{aligned}
$$

Clearly the marginal cost of additional overtime is unaffected by standard hours (and is determined only by the wage and the overtime premium), while the marginal cost of an additional worker is increased when standard hours are reduced, since more of this worker's wages must be paid at the overtime premium. Hence, the firm will substitute from workers to hours, an effect which obviously tends to decrease employment. Figure la shows the two marginal cost schedules for original standard hours $h_{s}{ }^{0}$ and reduced standard hours $h_{s}{ }^{1}$. This case is that of a firm originally having optimal hours such as $h{ }^{a}$. Employment will therefore fall, 
and the effect on weekly hours depends upon whether the scale effect and substitution from labor to capital dominates the substitution from workers to hours.

Figure 1a makes clear, however, that the original optimal hours (and the magnitude of the standard hours reduction) are critical for the response of the firm along the worker-hours margin. Consider a firm whose optimal hours are below even the new standard hours, at $h_{*}{ }^{b}$. If we assume that the law constrains hours to be at least standard hours, this firm will move its actual hours from the original kink point $h_{s}{ }^{0}$ to the new kink point $h_{s}{ }^{1}$. MC $h$ has thus not changed, while $\mathrm{MC}_{\mathrm{N}}$ has fallen, and the firm will substitute from hours to workers, the opposite of the previous case. The scale effect and the capital-labor substitution effect will work to increase employment. The overall effect is that hours will fall, while employment will rise.

We could extend the analysis to cases permitting firms to work less than standard hours (since this is possible in Germany, albeit not on a permanent basis). If a firm's original hours are below both the new and old standard, as in $h_{*}{ }^{b}$ in Figure 1a, the fall in standard hours will not affect its behavior. If its original hours are above the new standard hours, workers-hours substitution will depend on all the magnitudes involved (while scale and capital-labor substitution effects will tend to lower employment and hours).

For the firm with original optimal hours $h^{2}{ }^{a}$, the response to a fall in standard hours is different if we allow the overtime premium to be a positive function of the number of overtime hours. Many German industry contracts specify a $25 \%$ premium for the first ten overtime hours per week or two overtime hours per day, and a higher premium thereafter, and weekend work is also at a higher premium. If the fall in standard hours means the firm's current hours are now in the higher premium zone, as in Figure $1 \mathrm{~b}$, the $\mathrm{MC}_{\mathrm{h}}$ may rise more than the $\mathrm{MC}_{\mathrm{N}}$, and 
the firm will substitute from hours to workers. The net effect on employment will be ambiguous, and hours will fall. ${ }^{4}$

These cases make clear that if employment is to rise, there must be a large substitution from hours to workers. The finding that actual hours fall a lot is a necessary condition for work-sharing to be effective, but it is not a sufficient condition, since actual hours may be falling due to the scale effect or substitution to capital.

It is important to consider that other parameters might change in response to the reduction in standard hours. The overt concession in exchange for shorter standard hours on the part of German unions was the introduction of greater flexibility. Presumably flexibility has a positive scale effect, but it may be complementary with capital, and its effect on the trade-off between workers and hours must be examined in a more complex model.

Another consideration important for Germany is that the hourly (straight-time) wage apparently increased in response to standard hours deductions. A wage increase would cause a substitution from hours to workers due to the fixed cost of hiring a worker. ${ }^{5}$ The net effect on hours per worker is therefore negative, and on employment is ambiguous, although we would usually expect the scale effect and substitution to capital to predominate and lower employment. Worker-hours will fall. ${ }^{6}$

Finally, it is possible that individuals are more productive when they work fewer hours. Lower actual hours thus induce capital-saving technological progress. This has an ambiguous effect on the already ambiguous employment response, but should lead to a larger fall (or lower rise) in actual hours. Worker-hours still fall. 


\section{Previous Empirical Work}

A number of papers use aggregate manufacturing times series data to look at the effect of standard hours on actual hours per worker and employment, including Franz and König (1986), who examine Germany from 1964-84, an earlier period of reduction in standard hours. They report that a $1 \%$ reduction in standard hours raises employment by $1.09 \%$ and reduces hours per worker by $0.99 \%$, which implies a slight rise in worker-hours. De Regt (1988) finds an employment elasticity of -0.41 for the Netherlands in the period $1954-82$, and an hours per worker elasticity of 0.89 , implying a fall in worker-hours. Hart and Sharot (1978) find almost identical results for UK males in the period 1961-72. Wadhwani (1987) and Faini and Schiantarelli (1985) similarly estimate employment elasticities of -0.5 , although they do not estimate hours per worker elasticities. Brunello (1989), examining Japan in the period 1973-86, finds a different result: that reducing standard hours has essentially no effect on actual hours, although the employment elasticity is -0.34 , thus implying a rise in worker-hours.

Hart (1987) uses pooled data for 25 German industries for $1969-81$ and finds no response of employment to standard hours, but that a $1 \%$ reduction in standard hours reduces hours per worker (corrected for short time) by $1.2 \%$. The variation in standard hours in this pooled specification comes from both the cross-section and time-series. The only paper to examine these issues using micro-data is Hart and Wilson (1988), which uses British firm-level data pooled for the period 1978-82. They also find no response of employment to standard hours, but find that a one hour reduction in standard hours reduces actual hours by 0.77 hours.

None of these papers describes the variation in standard hours that identifies the coefficient of interest. With the time-series studies, standard hours may in many cases 
essentially be a downward trend, and may proxy for omitted variables that are also falling over time. Hart (1987) and Hart and Wilson (1988) use more suitable data, but the effect of pooling time-series and cross-section observations is unclear - the use of a panel technique would have been preferable.

Evidence on employment effects of the German standard hour reductions since 1984 is not abundant. Using full-time workers in the GSOEP, Hunt (1996) finds that hours per worker fell by $0.85-1$ hour for each hour fall in standard hours. A necessary condition for employment to rise is therefore satisfied. However, a second finding, that straight-time hourly wages rose 2-3\% for each hour reduction in standard hours, would work to reduce employment.

Stille and Zwiener (1987) attempt to tease out the effects of the 1985 standard hours reduction in the metal-working sector by examining aggregate trends for that sector without regression analysis. They judge that weekly overtime per person rose by half an hour due to the standard hours reduction of 1.5 hours and that short time was unaffected by reductions in standard hours, and influenced only by the business cycle. Their employment figures imply an elasticity of employment with respect to standard hours of about -0.5 , which lies between the elasticities found by the employers' association and the union. These results imply that workerhours stayed about the same. Finally, in the only econometric study of employment, Lehment (1991) finds that when wage restraint is controlled for, reductions in standard hours are insignificant in aggregate time series modelling employment growth for 1973-90. 
The principal data used are industry level data on manufacturing from the Statistisches Bundesamt. Firms with at least twenty employees are required to report certain information to the statistical office at the end of each month. The data used here refer to establishments belonging to these firms. The variables available are employment and wage bills for hourly workers (Arbeiter) and salaried workers (Angestellten) separately, worker-hours (total hours worked) for Arbeiter, and sales. Data are for 201 industries (a small number were excluded due to problems with their data). Attention is focused on the first phase of hours reductions from 1984 to 1989, although some results are presented for 1990-94 (after 1994 the industry classification changes).

Indices of collectively bargained wages (the average by industry for Arbeiter and Angestellten) are available from the same source. However, these data are available only quarterly, and have a different and more aggregated industry classification ( 45 categories), which must be matched to that used for the rest of the data. Collectively bargained wages rather than actual wages are used because the desired variable is the straight-time wage. Average actual wages would include overtime pay, and hence confound wages and hours. Collectively bargained wages are also slightly more exogenous to the firm, as there exists a certain amount of wage drift (raising of wages above the collectively bargained floor).

Published standard hours by industry are obtained from tables supplied by the WSI (Wirtschafts- und Sozialwissenschaftlichen Instituts des Deutschen Gewerkschaftbundes) (HansBöckler-Stiftung 1995). In certain industries where standard hours vary by region, the average across regions (weighted by employment) is computed. 
Figure 2 shows the means of the industry-level variables used. ${ }^{7}$ The means are unweighted, which means that compared to aggregate patterns, small industries are overrepresented. This appears to make average employment growth in the sample lower than in the aggregate (although aggregate manufacturing employment did fall 1986-7). The spikes in the Arbeiter wage bill series are due to end of year bonuses. Figure 3 selects four industries to represent the variety of standard hours reduction timing, and also plots employment of Arbeiter (hourly workers).

Part of the analysis uses data from the German Socio-Economic Panel for the years 19841989. In this section the standard hours variable is individual's response to the question "What are your collectively bargained weekly work hours without overtime?" (after the first survey, the questionnaire specifies that if the respondent has more than one job, that s/he should refer to the main job). The survey also asks respondents who are not working at the same job as in the previous interview questions that seek to establish why the respondent changed jobs. I have used these responses to identify which job changes occurred involuntarily (i.e. were fires or layoffs). This is inherently somewhat subjective, relies on accurate reporting by respondents, and assumes the quit/layoff distinction is meaningful. Therefore $I$ also conduct analysis assuming all separations are potentially involuntary.

When working with the individual data I focus on full-time workers (not possible in the industry data), and hence drop respondents who said they had less than 35 standard hours. I also drop workers who said their standard hours were greater than 45 , to remove the most obvious outliers (standard hours for all included industries were 40 or less throughout the sample period). I drop workers in fishing, agriculture, or private households, and the self-employed, 
for whom standard hours are not well-defined. I drop workers aged 55 or over, since during the period under consideration special agreements were reached in some industries to reduce the hours of older workers below those of others in the same industry or to allow early retirement. I also drop those doing apprenticeships and those under age 20 , although they could arguably be included. Finally, I drop those with missing actual or standard (agreed) hours, industry, firm size, job type (self-employed, salaried etc), education, wage or job change information. Figure 4 shows the transformation in standard hours for 1984-89 as reported by manufacturing workers in this sample.

\section{Industry Level Results}

The regressions using industry data are estimated using fixed effects. They include month dummies interacted with dummies for ten aggregate industries to control for seasonal patterns and are corrected for serial correlation of the errors with the iterative Cochrane-Orcutt procedure. In addition to controlling for standard hours in the regressions, I control for sales in each industry. This may be viewed as controlling for demand or, since sales and output are closely related, for the scale effect. Including sales should control for endogeneity of introduction of lower standard hours: if employers in industries expecting booms conceded lower standard hours, this could lead to a negative sign on standard hours in an employment regression (although a priori the endogeneity could go the other way). Thus specifications controlling for sales should be free of bias due to endogenous hours reductions, unless industries introducing lower standard hours were those expecting the capital to labor ratio to change in a particular 
direction, which does not seem compelling. Notice that if the more flexible use of hours caused a positive scale effect, this too will be controlled for.

Results will be presented both controlling for wages and omitting wages. Some component of changes in wages is part of the German work-sharing experiment, and the coefficient on standard hours with wages omitted is of interest. The counterfactual of unchanged wages is also of some interest, however, to get an idea of what might happen when standard hours are reduced in an institutional setting where wages might behave differently. ${ }^{8}$

Table 1 presents results of regressions omitting wages. The dependent variable of the first column is the log of Arbeiter (hourly-paid workers) at the end of the month. The coefficient on standard hours is negative and significant, with a magnitude indicating that a one hour reduction in standard hours would increase employment by $0.3 \%$. If confidence is placed in the theoretical prediction of a negative scale effect, and controlling for sales controls for the scale effect, then this result is an upper bound on the beneficial impact on employment of standard hours reductions. The net effect may even have been negative. Increased flexibility of hours could play a role, but is unlikely to be introducing a bias towards pessimistic results. Flexibility presumably does not cause substitution away from labor services; the effect on substitution between hours per worker and workers is unclear, but it is unlikely that flexibility reduced substitution from hours per worker substantially, since we shall see below that this substitution seems to be close to its theoretical maximum.

The second column examines the effect of standard hours on the total hours worked by Arbeiter over the month (worker-hours). The coefficient on standard hours is large and positive, indicating that a one hour reduction in standard hours reduced worker-hours by $2.1 \%$. If the 
coefficient is also picking up substitution toward labor services due to increased hours flexibility, the fall due to standard hours reductions alone would be more than $2.1 \%$.

The third column uses the ratio of worker-hours and workers to construct hours per worker (for Arbeiter), in order to see whether the effect of standard hours appears to be the same in the industry data as in the individual data of Hunt (1996). The coefficient suggests that a one hour fall in standard hours reduced hours per worker by $2.5 \%$. The individual level result of Hunt (1996) was that a full-time worker's typical work week fell by $0.85-1$ hour when standard hours fell one hour, or a $2.1-2.4 \%$ fall. The industry and individual data are thus fairly consistent. The coefficients on standard hours are fairly consistent across the three measures of Arbeiter labor inputs: a reduction of $2.5 \%$ in hours per worker (column 3 ) coupled with a rise of $0.3 \%$ in employment (column 1) implies a reduction in worker-hours of about $2.2 \%$, close to the $2.1 \%$ estimated in column 2 .

No data on worker-hours for Angestellten (salaried workers) are available, but the dependent variable of the fourth column is the log of Angestellten employed at the end of the month. The coefficient on standard hours suggests that reducing standard hours by one hour raised employment of Angestellten by $0.2 \%$, similar to the effect found for Arbeiter. The individual level data used in Hunt (1996) suggested that actual hours for Angestellten fell about one for one with standard hours, although these results were not as reliable as those for Arbeiter (Hunt 1996). Together with the results of column 4 this implies a large fall in Angestellten worker-hours, as for Arbeiter.

Thus for both Arbeiter and Angestellten, employment may have risen in response to a one hour reduction in standard hours, by $0.2-0.3 \%$, implying an elasticity of about -0.06 to 
-0.10 . This is on the low end of the range found by the existing literature. This employment rise had a considerable cost in terms of lost worker-hours, which fell by $2.1 \%$ in response to a one hour standard hour reduction, an elasticity of 0.84 .

However, since hourly wages are known from the results of Hunt (1996) to have risen when standard hours fell, the impact on the wage bill will be much less than on worker-hours, and could even be positive. If the wage bill rises, the group of workers that decided to reduce standard hours will be better off as a group even if some of them lose their job, and if redistribution occurred (for example through the union) each member of the group could be better off. Unions are sometimes modelled as wage-bill maximizers. Columns 5 and 6 examine the influence of standard hours on the wage bills of Arbeiter and Angestellten, and the coefficients on standard hours are negative and significant. The rises of $2.7 \%$ (for Arbeiter) and $3.9 \%$ (for Angestellten) associated with a one hour reduction in standard hours seem large in light of the results of Hunt (1996), which found that straight-time hourly wages rose 2-3\%.

Table 2 adds the indices of collectively bargained wages for Arbeiter and Angestellten to the regressions of Table 1. The coefficients on the added variables do not always have the expected signs: in particular, the coefficients on the two wage variables are essentially the same in the Arbeiter regression as in the Angestellten regression. It is thus not entirely clear what is being captured by the wage variables. The coefficients on standard hours are less significant than in Table 1, but generally paint a less optimistic picture. This is unexpected, since controlling for what is thought to be a wage rise should make standard hours reductions look better for employment. The coefficient for Angestellten changes sign to become significant and positive, indicating that reducing standard hours by one hour reduced employment by $0.2 \%$. 
The sign changes for Arbeiter too, although the coefficient is insignificant. The coefficient in the regression for worker-hours becomes small and insignificant (this change is in the expected direction). Finally, the coefficient on hours per worker falls. The results for worker-hours and hours per worker could have the interpretation that some of their fall in response to reductions in standard hours was in fact due to the accompanying wage rise.

Table 3 presents the results of weighted regressions. Regressions are weighted by the average level of the dependent variable, with the exception of the hours per worker regression, which is weighted by average number of Arbeiter. The weighted regressions have the advantage that means are close to the means across workers. However, if the correct unit of analysis is in fact the firm, and aggregation has uncertain effects, it may not be an improvement to downweight observations on small industries. Weighting increases the contribution to the estimates of the large industries that struck in 1984 under IG Metall, and therefore provides an indication as to whether the strike could be influencing the results.

The results are qualitatively similar to the unweighted results, although the magnitudes of the standard hours coefficients differ, especially for Arbeiter worker-hours and the wage bills, where the coefficients are considerably smaller and larger, respectively. The results of this table suggest that a one hour fall in standard hours leads to a $0.26 \%$ rise in employment of Angestellten and a $0.14 \%$ rise in employment of Arbeiter.

The regressions presented so far have not taken into account the fact that in some cases firms might anticipate reductions in standard hours, since these were often known in advance, nor that, particularly in cases where reductions took effect immediately they were agreed, the firms might need some time to respond. The regressions of Table 4 add to the regressors six 
leads and six lags of standard hours, and the sum of all the standard hours coefficients, representing the steady-state effect, is reported. The results of these (unweighted) regressions are similar to the regressions of Table 1 including only current standard hours, although the standard hours "coefficient" is larger, most notably for the Arbeiter regression. Hence a one hour reduction in standard hours is associated with a $2.7 \%$ fall in Arbeiter worker-hours, a $0.7 \%$ rise in Arbeiter employment, and a $0.3 \%$ rise in Angestellten employment. The implied elasticity for Arbeiter, -0.26 , is still lower than those estimated in the time-series literature. These results and those of Table 1 are preferred to the specifications including wages or using weighting.

A final set of results based on data for 1990-1994 is presented in Table 5. This period is not as good for the purposes of this study, since a widespread move to begin cutting hours between mid-1989 and mid-1990 means that all industries have falling standard hours. The effect of interest is thus identified from differing rates of the fall in standard hours. Also, the last years of the data seem to be of poorer quality, and $8 \%$ of the observations are missing for the period 1990-1994. Table 5 does not provide evidence that cuts in standard hours increase employment. ${ }^{9}$

The specification that has shown the most beneficial effects of standard hours reductions is the coefficient of -0.0066 in the Arbeiter equation using leads and lags (column 1 of Table 4). Average standard hours in the sample fell 1.7 hours from 1984 to 1989 , so this coefficient implies a $1.1 \%$ employment gain due to work-sharing. Compared to the growth in manufacturing employment of $5.2 \%$ from $1984-89$ this is significant, although not large. However, perhaps a better comparison is with the level of employment growth that was hoped 
for over this period. Employment in the U.S. grew $11.6 \%$ and the employment to population ratio grew $7.3 \%$ (compared to $3.2 \%$ in Germany). Clearly, the employment growth achieved in Germany through work-sharing is not close to bridging the German-American employment growth gap. Furthermore, the large associated reductions in worker-hours suggest that the standard hours reductions introduced a serious distortion and may have resulted in considerable output loss.

\section{Individual Level Results}

Table 6 presents results from the GSOEP on the probability of a worker separating involuntarily from the current job. A fixed effects conditional logit specification is used. The regressors include year dummies, the current wage, current standard hours (as reported by the respondent), and expected standard hours for the following year, to allow workers to anticipate announced changes. Expected standard hours are calculated by averaging the standard hours responses in the following year of those in the individual's current industry and job type. The results are similar (i.e. the coefficient is also insignificant) if expected standard hours are based on published sources. Industry dummies are not generally included as, surprisingly, the hypothesis that their coefficients were jointly zero could only be rejected in one regression. Arbeiter in services and Angestellten in manufacturing are not broken out separately, as too few separations identify the coefficients of interest. Manufacturing for the individual data does not include construction, for consistency with the industry data.

For Arbeiter in all industries grouped together, the coefficient on standard hours is positive and significant, suggesting a $7 \%$ decline in the probability of involuntary separation. ${ }^{10}$ 
Since the probability of an involuntary separation is $4.2 \%$ for this group, a one hour reduction in standard hours would reduce this probability to $3.8 \%$, raising employment by about $0.3 \%$ (ignoring any effect on hires, of course). This falls within the range found using industry data. If the effect on hires is of a similar magnitude, the total effect would be similar to the largest effect found with industry data. For other groups the coefficient on standard hours is insignificant, except when the whole sample is used. The similarity of the coefficients for Arbeiter in manufacturing, all Arbeiter, and the whole sample suggests that reducing standard hours has similar employment effects in services and manufacturing.

Expected standard hours always has an insignificant coefficient. Insofar as the coefficient for Arbeiter in manufacturing is insignificant, these results do not accord with the industry level data for manufacturing. Even for this group, the number of separations that identify the coefficient is not large, however. Notice that the wage variable has a negative sign, and is hence probably capturing information about how the firm values the individual, rather than a labor demand story about how the firm responds to exogenous union wage increases.

If the regressions are rerun with the probability of any type of separation as the dependent variable, the results are similar in terms of significance, but coefficients are smaller.

\section{Conclusions}

Using manufacturing data on 201 detailed industries for $1984-89$, I find that reductions in standard hours were associated with rises in employment. I find that, in the preferred specifications, a one hour fall in standard hours raised employment of hourly workers (Arbeiter) by $0.3-0.7 \%$ and employment of salaried workers (Angestellten) by $0.2-0.3 \%$. However, I find 
that worker-hours of hourly workers (Arbeiter) fell by $2-3 \%$ in response to a one hour reduction in standard hours. These results are conditional on sales, which removes endogeneity associated with the adoption of lower standard hours, but may to some extent control for the scale effect, expected to be negative. Hence, the employment rises may be upper bounds and the workerhours fall a lower bound. The implied elasticities for employment are at the low end of the range in the existing literature on work-sharing, and the implied growth in employment of at most $1.1 \%$ (in response to a 1.7 hour reduction in mean standard hours) is small compared with growth in U.S. employment over the same period.

Due to a rise in straight-time hourly wages, the wage bill actually rose in conjunction with reduced standard hours, despite reduced worker-hours, for both Arbeiter and Angestellten. This indicates that workers as a group benefited from hours reductions.

The employment results from industry level data are supported by analysis of the probability of an involuntary separation in the individual level Socio-Economic Panel data. For Arbeiter in manufacturing and services together a one hour reduction in standard hours reduced the probability of an involuntary separation by $7 \%$, a magnitude which would imply an employment rise of $0.3 \%$, similar to the industry-level results. For Angestellten standard hours had no significant effect on separations.

Industry-level results for the period 1990-1994 are more pessimistic, and suggest that employment fell when standard hours fell. Although this period, when standard hours were falling in all industries, is less suitable for study, these results do caution that employment outcomes could be different in different economic environments. 
The good news from the first phase of Germany's work-sharing experiment is thus that employment rose, and that the wage bill increased. The bad news is that employment did not rise enough to bring the German employment growth rate close to the American rate, and the large fall in worker-hours indicates that an important distortion was introduced, which may have caused loss of output. 
References

Bell, Linda and Richard Freeman. 1995. "Why Do Americans and Germans Work Different Hours?". In Friedrich Buttler et. al. eds. Institutional Frameworks and Labor Market Performance: Comparative views on the U.S. and German Economies Ruttledge, New York.

Booth, Alison and Martin Ravallion. 1993. "Employment and Length of the Working Week in a Unionized Economy in which Hours of Work Influence Productivity." Economic Record pp.428-436.

Booth, Alison and Fabio Schiantarelli. 1987. "The Employment Effects of a Shorter Working Week". Economica pp. 237-248.

Bosch, Gerhard. 1990. "From 40 to 35 hours: Reduction and flexibilisation of the working week in the Federal Republic of Germany". International Labour Review pp.611-627.

Bosch, Gerhard et. al. 1988. Arbeitszeitverkürzung im Betrieb; Die Umsetzung der 38.5-StundenWoche in der Metall-, Druck- und Holzindustrie sowie im Einzelhandel Köln.

Bosch, Gerhard and Steffen Lehndorff. (n.d.) "Annual Working Hours in Germany". Institut für Arbeit und Technik mimeo.

Brunello, Giorgio. 1989. "The Employment Effects of Shorter Working Hours: An Application to Japanese Data." Economica pp. 473-86.

Calmfors, Lars. 1985. "Work Sharing, Employment and Wages." European Economic Review pp.293-309.

deRegt, Erik. 1988. "Labor Demand and Standard Working Time in Dutch Manufacturing, 1954-1982." In Robert Hart ed. Employment, Unemployment and Labor Utilization Unwin Hyman, Boston.

Earle, John, and John Pencavel. 1990. "Hours of Work and Trade Unionism". Joumal of Labor Economics pp.S150-174.

European Industrial Relations Review various issues.

Faini, Riccardo and Fabio Schiantarelli. 1985. "A Unified Frame for Firms' Decisions: Theoretical Analysis and Empirical Application to Italy, 1970-1980. "In Daniel Weiserbs, ed., International Studies in Economics and Econometrics. Amsterdam: Martinus Nijhoff. 
Franz, Wolfgang and Heinz König. 1986. "The Nature and Causes of Unemployment in the Federal Republic of Germany since the 1970s: An Empirical Investigation." Economica pp. S219-S244.

Freeman, Richard. 1995. "Work-Sharing to Full Employment: Serious Option or Populist Fallacy?". Harvard University mimeo.

Hamermesh, Daniel. 1993. Labor Demand. Princeton University Press.

Hamermesh, Daniel. 1995. "The Demand for Workers, Hours and Days". University of Texas mimeo.

Hans-Böckler-Stiftung des Deutschen Gewerkschaftbundes. 1995. WSI-Informationen zur Tarifpolitik: Arbeitszeitkalendar West und Ost 1995. Düsseldorf.

Hart, Robert. 1987. Working Time and Employment Allen and Unwin, Boston.

Hart, Robert and T Sharot. 1978. "The Short-Run Demand for Workers and Hours: A Recursive Model." Review of Economic Studies pp.299-309.

Hart, Robert and Nicholas Wilson. 1988. "The Demand for Workers and Hours: Micro Evidence from the UK Metal Working Industry." In Robert Hart ed. Employment, Unemployment and Labor Utilization Unwin Hyman, Boston.

Hoel, Michael. 1987. "Can Shorter Working Time Reduce Unemployment?" In C.H Siven, ed. Unemployment and Labor Utilization Unwin Hyman, Boston.

Houpis, George. 1993. "The Effect of Lower Hours of Work on Wages and Employment." Centre for Economic Performance, LSE, mimeo.

Hunt, Jennifer. 1995. "Which Slows Employment Adjustment More: Firing Costs or Restrictions on Hours Per Worker?". Yale University mimeo.

Hunt, Jennifer. 1996. "The Response of Wages and Actual Hours Worked to the Reduction of Standard Hours in Germany." Hoover Institution mimeo.

Institut für Arbeitsmarkt- und Berufsforschung (IAB). Various tables.

König, Heinz and Winfried Pohlmeier. 1988. "A Dynamic Model of Labor Utilization." In Robert Hart ed. Employment, Unemployment and Labor Utilization Unwin Hyman, Boston. 
Lehment, Harmen. 1991. "Lohnzurückhaltung, Arbeitszeitverkürzung und Beschäftigung. Eine empirische Untersuching für die Bundesrepublik Deutschland 1973-1990." Die Weltwirtschaft pp.72-85.

Senatsverwaltung für Arbeit und Frauen - Beirat Arbeitsmarktpolitik. 1995a. Berliner Erklärung - Zur Halbierung der Arbeitslosigkeit bis zum Jahr 2000 Berlin.

Senatsverwaltung für Arbeit und Frauen - Beirat Arbeitsmarktpolitik. 1995b. Berliner Memorandum zur Arbeitszeitpolitik 2000 Berlin.

Stille, Frank and Rudolf Zwiener. 1987. "Beschäftigungswirkungen der Arbeitszeitverkürzung von 1985 in der Metallindustrie." Deutsches Institut für Wirtschaftsforschung Wochenbericht pp. 273-279.

Wadhwani, Sushil. 1987. "The Effects of Inflation and Real Wages on Employment." Economica pp.21-40.

WSI-Mitteilungen Zeitschrift des Wirtschafts- und Sozialwissenschaftlichen Instituts des Deutschen Gewerkschaftbundes GmbH. Various issues. Bund Verlag, Köln. 


\section{Notes}

1. European Industrial Relations Review November 1983.

2. Under the old system, a worker working more than eight hours in any given day was entitled to overtime, as is the case currently in California. Generally in the United States the forty weekly hours may be spread in any way across the week with no obligation to pay overtime, and the new German agreements allow for even longer windows.

3. A large literature documents the implementation of standard hours reductions. See, for example, Bosch (1990), Bosch et. al. (1988), Bosch and Lehndorff (n.d.), European Industrial Relations Review (various issues), Stille (1995), WSI-Mitteilungen (various issues).

4. For theoretical examinations of work-sharing, see Booth and Ravallion (1993), Booth and Schiantarelli (1987), Calmfors (1985), Freeman (1995), Hart (1987), and König and Pohlmeier (1988).

5. To see this, write the ratio of the marginal costs, and take the derivative of this with respect to the wage:

$$
\frac{\partial \frac{M C_{N}}{M C_{h}}}{\partial w}=\frac{1}{(1+p)^{2} w^{2} N^{2}}\left(\left[h+p\left(h-h_{s}\right)\right](1+p) w N-\left[w h+f+p w\left(h-h_{s}\right)\right](1+p) N\right)
$$

This is less than zero if $\mathrm{f}>0$.

6. See Calmfors (1985), Hoel (1987) and Houpis (1993) for theoretical analysis of the response of wages to cuts in standard hours.

7. A small number of industries (five) have data missing in some years - they are excluded from the figure so as not to make patterns look artificially jerky.

8. Like changes in standard hours, changes in wages cause a scale effect, and this will to some extent be proxied for by sales in both specifications.

9. A possible explanation of why results for the 90 s seem less optimistic than results for the 80 s as follows. Industries with more variable sales may be those who reduced standard hours earliest and most if employers were keen to gain hours flexibility. If these industries also have larger business cycle swings, they may have had greater employment rises in the upturn of the 80s, and greater losses in the more uncertain early 90s. In this case the 80 s results are overly optimistic in terms of employment gains.

10. The elasticity representing the effect of $h_{s}$ on $P(O T>0)$ is calculated from

$$
\frac{\partial \log \overline{P(\text { Fired; } ; X)}}{\partial \log h_{s}}=\beta_{h_{s}} \bar{h}_{s}[1-\overline{P(\text { Fired } ; X)}]
$$


Table 1: The Effect of Standard Hours on Labor Inputs and Wage Bills

\begin{tabular}{|c|c|c|c|c|c|c|}
\hline & \multicolumn{4}{|c|}{ Labor services } & \multicolumn{2}{|c|}{ Wage bills } \\
\hline & \multicolumn{3}{|c|}{ Arbeiter (hourly-paid workers) } & \multirow{2}{*}{$\begin{array}{l}\text { Angestell- } \\
\text { en } \\
\text { (salaried } \\
\text { workers) }\end{array}$} & \multirow[t]{2}{*}{ Arbeiter } & \multirow{2}{*}{$\begin{array}{c}\text { Angestell- } \\
\text { ten }\end{array}$} \\
\hline & Arbeiter & $\begin{array}{l}\text { Worker- } \\
\text { hours }\end{array}$ & $\begin{array}{l}\text { Hours } \\
\text { per } \\
\text { worker }\end{array}$ & & & \\
\hline $\begin{array}{l}\text { Standard } \\
\text { hours }\end{array}$ & $\begin{array}{l}-0.0026 \\
(0.0006)\end{array}$ & $\begin{array}{c}0.0209 \\
(0.0010)\end{array}$ & $\begin{array}{c}0.0253 \\
(0.0007)\end{array}$ & $\begin{array}{l}-0.0016 \\
(0.0006)\end{array}$ & $\begin{array}{l}-0.027 \\
(0.001)\end{array}$ & $\begin{array}{l}-0.039 \\
(0.002)\end{array}$ \\
\hline Sales (log) & $\begin{array}{c}0.031 \\
(0.001)\end{array}$ & $\begin{array}{c}0.268 \\
(0.003)\end{array}$ & $\begin{array}{c}0.131 \\
(0.003)\end{array}$ & $\begin{array}{c}0.0119 \\
(0.0006)\end{array}$ & $\begin{array}{c}0.138 \\
(0.004)\end{array}$ & $\begin{array}{c}0.050 \\
(0.003)\end{array}$ \\
\hline $\begin{array}{l}\text { Agg. industry } \\
* \text { Month } \\
\text { dummies? }\end{array}$ & yes & yes & yes & yes & yes & yes \\
\hline $\begin{array}{l}\text { Durbin- } \\
\text { Watson }\end{array}$ & 0.23 & 0.70 & 1.62 & 0.19 & 0.92 & 0.69 \\
\hline$\rho$ (mean of $\rho_{\mathrm{i}}$ ) & $\begin{array}{c}0.94 \\
(0.04)\end{array}$ & $\begin{array}{c}0.50 \\
(0.09)\end{array}$ & -- & $\begin{array}{c}0.93 \\
(0.04)\end{array}$ & $\begin{array}{c}0.57 \\
(0.09)\end{array}$ & $\begin{array}{c}0.66 \\
(0.08)\end{array}$ \\
\hline $\mathrm{N}, \mathrm{T}$ & \multicolumn{6}{|c|}{201,72} \\
\hline
\end{tabular}

Notes:

a. The dependent variables are in logs. Arbeiter (hourly-paid workers) and Angestellten (salaried workers) are measured at the end of the month, worker-hours and wage bills are totals for the month. Hours per worker is the ratio of (Arbeiter) worker-hours and Arbeiter.

b. Data are monthly, for 1984-89.

c. Estimation is by fixed effects. Where a value for $\rho$ is reported, serial correlation has been corrected for using iterative Cochrane-Orcutt. The average of the industry-specific $\rho$ 's is reported. The Durbin Watson test refers to the uncorrected results. 
Table 2: The Effect of Standard Hours on Labor Inputs, With Wages as Covariates

\begin{tabular}{|c|c|c|c|c|}
\hline & \multicolumn{4}{|c|}{ Labor services } \\
\hline & \multicolumn{3}{|c|}{ Arbeiter (hourly-paid workers) } & \multirow{2}{*}{$\begin{array}{c}\text { Angestellen } \\
\text { (salaried } \\
\text { workers) }\end{array}$} \\
\hline & Arbeiter & $\begin{array}{l}\text { Worker- } \\
\text { hours }\end{array}$ & $\begin{array}{l}\text { Hours per } \\
\text { worker }\end{array}$ & \\
\hline Standard hours & $\begin{array}{c}0.0009 \\
(0.0009)\end{array}$ & $\begin{array}{c}0.0023 \\
(0.0031)\end{array}$ & $\begin{array}{c}0.0098 \\
(0.0020)\end{array}$ & $\begin{array}{c}0.0021 \\
(0.0009)\end{array}$ \\
\hline Sales (log) & $\begin{array}{c}0.031 \\
(0.001) \\
\end{array}$ & $\begin{array}{r}0.278 \\
(0.003) \\
\end{array}$ & $\begin{array}{c}0.138 \\
(0.003) \\
\end{array}$ & $\begin{array}{c}0.011 \\
(0.001) \\
\end{array}$ \\
\hline Arbeiter wage (log) & $\begin{array}{r}0.187 \\
(0.039) \\
\end{array}$ & $\begin{array}{l}-0.107 \\
(0.126) \\
\end{array}$ & $\begin{array}{l}-0.263 \\
(0.083) \\
\end{array}$ & $\begin{array}{r}0.196 \\
(0.037) \\
\end{array}$ \\
\hline $\begin{array}{l}\text { Angestellten wage } \\
(\log )\end{array}$ & $\begin{array}{l}-0.245 \\
(0.040) \\
\end{array}$ & $\begin{array}{l}-0.327 \\
(0.127) \\
\end{array}$ & $\begin{array}{r}0.076 \\
(0.083) \\
\end{array}$ & $\begin{array}{l}-0.251 \\
(0.038) \\
\end{array}$ \\
\hline $\begin{array}{l}\text { Aggregate industry * } \\
\text { Month dummies? }\end{array}$ & yes & yes & yes & yes \\
\hline Durbin-Watson & 0.27 & 0.79 & 1.66 & 0.22 \\
\hline$\rho\left(\right.$ mean of $\left.\rho_{\mathrm{i}}\right)$ & $\begin{array}{c}0.94 \\
(0.04)\end{array}$ & $\begin{array}{c}0.49 \\
(0.10)\end{array}$ & -- & $\begin{array}{c}0.93 \\
(0.04)\end{array}$ \\
\hline $\mathrm{N}, \mathrm{T}$ & \multicolumn{4}{|c|}{201,72} \\
\hline
\end{tabular}

Notes:

a. The dependent variables are in logs. Arbeiter (hourly-paid workers) and Angestellten (salaried workers) are measured at the end of the month, worker-hours is the total for the month. Hours per worker is the ratio of (Arbeiter) worker-hours and Arbeiter.

b. The wage is the log of the collectively bargained wage.

c. Data are monthly, for 1984-89.

d. Estimation is by fixed effects. Where a value for $\rho$ is reported, serial correlation has been corrected for using iterative Cochrane-Orcutt. The average of the industry-specific $\rho$ 's is reported. The Durbin Watson test refers to the uncorrected results. 
Table 3: Results of Weighted Regressions

\begin{tabular}{|c|c|c|c|c|c|c|}
\hline & \multicolumn{4}{|c|}{ Labor services } & \multicolumn{2}{|c|}{ Wage bills } \\
\hline & \multicolumn{3}{|c|}{ Arbeiter (hourly-paid workers) } & \multirow{2}{*}{$\begin{array}{l}\text { Angestell- } \\
\text { en } \\
\text { (salaried } \\
\text { workers) }\end{array}$} & \multirow[t]{2}{*}{ Arbeiter } & \multirow{2}{*}{$\begin{array}{l}\text { Angestell- } \\
\text { ten }\end{array}$} \\
\hline & Arbeiter & $\begin{array}{l}\text { Worker- } \\
\text { hours }\end{array}$ & $\begin{array}{l}\text { Hours } \\
\text { per } \\
\text { worker }\end{array}$ & & & \\
\hline $\begin{array}{l}\text { Standard } \\
\text { hours }\end{array}$ & $\begin{array}{l}-0.0014 \\
(0.0005)\end{array}$ & $\begin{array}{c}0.0121 \\
(0.0007)\end{array}$ & $\begin{array}{c}0.0305 \\
(0.0007)\end{array}$ & $\begin{array}{l}-0.0026 \\
(0.0005)\end{array}$ & $\begin{array}{l}-0.060 \\
(0.001)\end{array}$ & $\begin{array}{l}-0.076 \\
(0.002)\end{array}$ \\
\hline Sales $(\log )$ & $\begin{array}{c}0.013 \\
(0.001) \\
\end{array}$ & $\begin{array}{c}0.301 \\
(0.003) \\
\end{array}$ & $\begin{array}{c}0.181 \\
(0.003) \\
\end{array}$ & $\begin{array}{c}0.0024 \\
(0.0005) \\
\end{array}$ & $\begin{array}{c}0.169 \\
(0.004) \\
\end{array}$ & $\begin{array}{c}0.053 \\
(0.003) \\
\end{array}$ \\
\hline $\begin{array}{l}\text { Agg. industry } \\
* \text { Month } \\
\text { dummies? }\end{array}$ & yes & yes & yes & yes & yes & yes \\
\hline $\begin{array}{l}\text { Durbin- } \\
\text { Watson }\end{array}$ & 0.22 & 1.03 & 1.76 & 0.20 & 1.07 & 0.73 \\
\hline$\rho\left(\right.$ mean of $\left.\rho_{\mathrm{i}}\right)$ & $\begin{array}{c}0.94 \\
(0.03) \\
\end{array}$ & $\begin{array}{c}0.49 \\
(0.09) \\
\end{array}$ & -- & $\begin{array}{c}0.93 \\
(0.04) \\
\end{array}$ & $\begin{array}{c}0.52 \\
(0.10) \\
\end{array}$ & $\begin{array}{c}0.63 \\
(0.09) \\
\end{array}$ \\
\hline $\mathrm{N}, \mathrm{T}$ & \multicolumn{6}{|c|}{201,72} \\
\hline
\end{tabular}

Notes:

a. The dependent variables are in logs.

b. Data are monthly, for 1984-89.

c. Estimation is by fixed effects. Where a value for $\rho$ is reported, serial correlation has been corrected for using iterative Cochrane-Orcutt. The average of the industry-specific $\rho$ 's is reported. The Durbin Watson test refers to the uncorrected results.

d. Regressions are weighted by the average over the period of the dependent variable (in levels). (For hours per worker the weight is the average number of Arbeiter.) 
Table 4: Results of Regressions With Leads and Lags

\begin{tabular}{|c|c|c|c|c|c|c|}
\hline & \multicolumn{4}{|c|}{ Labor services } & \multicolumn{2}{|c|}{ Wage bills } \\
\hline & \multicolumn{3}{|c|}{ Arbeiter (hourly-paid workers) } & \multirow{2}{*}{$\begin{array}{l}\text { Angestell- } \\
\text { en } \\
\text { (salaried } \\
\text { workers) }\end{array}$} & \multirow[t]{2}{*}{ Arbeiter } & \multirow{2}{*}{$\begin{array}{c}\text { Angestell- } \\
\text { ten }\end{array}$} \\
\hline & Arbeiter & $\begin{array}{c}\text { Worker- } \\
\text { hours }\end{array}$ & $\begin{array}{c}\text { Hours } \\
\text { per } \\
\text { worker }\end{array}$ & & & \\
\hline $\begin{array}{l}\text { Sum of } \\
\text { standard hour } \\
\text { coefficients }\end{array}$ & $\begin{array}{l}-0.0066 \\
(0.0017)\end{array}$ & $\begin{array}{c}0.0272 \\
(0.0012)\end{array}$ & $\begin{array}{c}0.0311 \\
(0.0007)\end{array}$ & $\begin{array}{l}-0.0032 \\
(0.0012)\end{array}$ & $\begin{array}{l}-0.046 \\
(0.001)\end{array}$ & $\begin{array}{l}-0.067 \\
(0.002)\end{array}$ \\
\hline Sales (log) & $\begin{array}{c}0.030 \\
(0.001)\end{array}$ & $\begin{array}{c}0.270 \\
(0.003)\end{array}$ & $\begin{array}{c}0.133 \\
(0.003)\end{array}$ & $\begin{array}{c}0.012 \\
(0.001)\end{array}$ & $\begin{array}{c}0.140 \\
(0.004)\end{array}$ & $\begin{array}{c}0.049 \\
(0.003)\end{array}$ \\
\hline $\begin{array}{l}\text { Agg. industry } \\
\text { * Month } \\
\text { dummies? }\end{array}$ & yes & yes & yes & yes & yes & yes \\
\hline $\begin{array}{l}\text { Durbin- } \\
\text { Watson }\end{array}$ & 0.24 & 0.72 & 1.63 & 0.20 & 0.92 & 0.70 \\
\hline$\rho\left(\right.$ mean of $\left.\rho_{\mathrm{i}}\right)$ & $\begin{array}{c}0.94 \\
(0.04)\end{array}$ & $\begin{array}{c}0.50 \\
(0.09)\end{array}$ & -- & $\begin{array}{c}0.93 \\
(0.04) \\
\end{array}$ & $\begin{array}{c}0.54 \\
(0.09)\end{array}$ & $\begin{array}{c}0.64 \\
(0.08)\end{array}$ \\
\hline $\mathrm{N}, \mathrm{T}$ & \multicolumn{6}{|c|}{201,72} \\
\hline
\end{tabular}

Notes:

a. The dependent variables are in logs.

b. The covariates include six leads and lags of standard hours. The sum of the coefficients on the leads, lags and contemporaneous variables are reported.

c. Data are monthly, for 1984-89.

d. Estimation is by fixed effects. Where a value for $\rho$ is reported, serial correlation has been corrected for using iterative Cochrane-Orcutt. The average of the industry-specific $\rho$ 's is reported. The Durbin Watson test refers to the uncorrected results. 
Table 5: Results of Regressions for 1990-1994

\begin{tabular}{|c|c|c|c|c|c|c|}
\hline & \multicolumn{4}{|c|}{ Labor services } & \multicolumn{2}{|c|}{ Wage bills } \\
\hline & \multicolumn{3}{|c|}{ Arbeiter (hourly-paid workers) } & \multirow{2}{*}{$\begin{array}{c}\text { Angestell- } \\
\text { en } \\
\text { (salaried } \\
\text { workers) }\end{array}$} & \multirow[t]{2}{*}{ Arbeiter } & \multirow{2}{*}{$\begin{array}{l}\text { Angestell } \\
\text { ten }\end{array}$} \\
\hline & Arbeiter & $\begin{array}{l}\text { Worker- } \\
\text { hours }\end{array}$ & $\begin{array}{c}\text { Hours } \\
\text { per } \\
\text { worker }\end{array}$ & & & \\
\hline $\begin{array}{l}\text { Standard } \\
\text { hours }\end{array}$ & $\begin{array}{c}0.0045 \\
(0.0009)\end{array}$ & $\begin{array}{c}0.1014 \\
(0.0022) \\
\end{array}$ & $\begin{array}{c}0.0084 \\
(0.0009) \\
\end{array}$ & $\begin{array}{c}0.0062 \\
(0.0008)\end{array}$ & $\begin{array}{c}0.044 \\
(0.002)\end{array}$ & $\begin{array}{l}-0.032 \\
(0.002)\end{array}$ \\
\hline Sales $(\log )$ & $\begin{array}{c}0.031 \\
(0.001) \\
\end{array}$ & $\begin{array}{c}0.252 \\
(0.004) \\
\end{array}$ & $\begin{array}{c}0.145 \\
(0.003) \\
\end{array}$ & $\begin{array}{c}0.026 \\
(0.001) \\
\end{array}$ & $\begin{array}{c}0.142 \\
(0.004) \\
\end{array}$ & $\begin{array}{c}0.060 \\
(0.004) \\
\end{array}$ \\
\hline $\begin{array}{l}\text { Agg. industry } \\
{ }^{*} \text { Month } \\
\text { dummies? }\end{array}$ & yes & yes & yes & yes & yes & yes \\
\hline $\begin{array}{l}\text { Durbin- } \\
\text { Watson }\end{array}$ & 0.38 & 0.66 & 1.47 & 0.37 & 0.91 & 0.82 \\
\hline$\rho\left(\right.$ mean of $\left.\rho_{\mathrm{i}}\right)$ & $\begin{array}{r}0.97 \\
(0.03) \\
\end{array}$ & $\begin{array}{c}0.66 \\
(0.10) \\
\end{array}$ & $\begin{array}{c}0.22 \\
(0.13) \\
\end{array}$ & $\begin{array}{c}0.92 \\
(0.05) \\
\end{array}$ & $\begin{array}{c}0.56 \\
(0.11)\end{array}$ & $\begin{array}{c}0.57 \\
(0.10)\end{array}$ \\
\hline $\mathrm{N}, \mathrm{T}$ & \multicolumn{6}{|c|}{201,60} \\
\hline
\end{tabular}

Notes:

a. The dependent variables are in logs.

b. Data are monthly, for 1990-94.

c. Estimation is by fixed effects. Where a value for $\rho$ is reported, serial correlation has been corrected for using iterative Cochrane-Orcutt. The average of the industry-specific $\rho$ 's is reported. The Durbin Watson test refers to the uncorrected results.

d. Regressions are weighted by the average over the period of the dependent variable (in levels). (For hours per worker the weight is the average number of Arbeiter.) 
Table 6: The Effect of Standard Hours on the Probability of Involuntary Separation

\begin{tabular}{||l|c|c|c|c|c||}
\cline { 2 - 6 } \multicolumn{1}{c|}{} & \multicolumn{2}{c|}{ Arbeiter (hourly) } & \multicolumn{2}{c||}{ Angestellten (salaried) } & All \\
\cline { 2 - 7 } \multicolumn{1}{c|}{} & $\begin{array}{c}\text { Manufact- } \\
\text { uring }\end{array}$ & All & Services & All & All \\
\hline \hline Standard hours & $\begin{array}{c}0.215 \\
(0.206)\end{array}$ & $\begin{array}{c}0.191 \\
(0.094)\end{array}$ & $\begin{array}{c}-0.235 \\
(0.233)\end{array}$ & $\begin{array}{c}0.090 \\
(0.143)\end{array}$ & $\begin{array}{c}0.149 \\
(0.072)\end{array}$ \\
\hline $\begin{array}{l}\text { Expected } \\
\text { standard hours } \\
\text { following year }\end{array}$ & $\begin{array}{c}0.985 \\
(0.939)\end{array}$ & $\begin{array}{c}-0.417 \\
(0.303)\end{array}$ & $\begin{array}{c}0.067 \\
(0.824)\end{array}$ & $\begin{array}{c}0.120 \\
(0.500)\end{array}$ & $\begin{array}{c}-0.086 \\
(0.237)\end{array}$ \\
\hline Wage (log) & $\begin{array}{c}-1.358 \\
(1.196)\end{array}$ & $\begin{array}{c}-0.818 \\
(0.527)\end{array}$ & $\begin{array}{c}-0.583 \\
(0.949)\end{array}$ & $\begin{array}{c}-0.296 \\
(0.687)\end{array}$ & $\begin{array}{c}-0.600 \\
(0.396)\end{array}$ \\
\hline Year dummies? & yes & yes & yes & yes & yes \\
\hline Industry dummies? & yes & no & no & no & no \\
\hline N*T (total obs) & 5015 & 7362 & 2952 & 4656 & 12018 \\
\hline N (cross-section) & 1732 & 2685 & 1127 & 1768 & 4453 \\
\hline $\begin{array}{l}\text { Mean of dependent } \\
\text { variable }\end{array}$ & 0.034 & 0.042 & 0.038 & 0.032 & 0.038 \\
\hline \hline
\end{tabular}

Notes:

1. Individual level data from GSOEP for 1984-1988.

2. Estimation is fixed effects conditional logit.

3. Expected standard hours in the following year is the average in the following year of standard hours responses in the individual's current industry and job type.

4. Manufacturing does not include construction. 

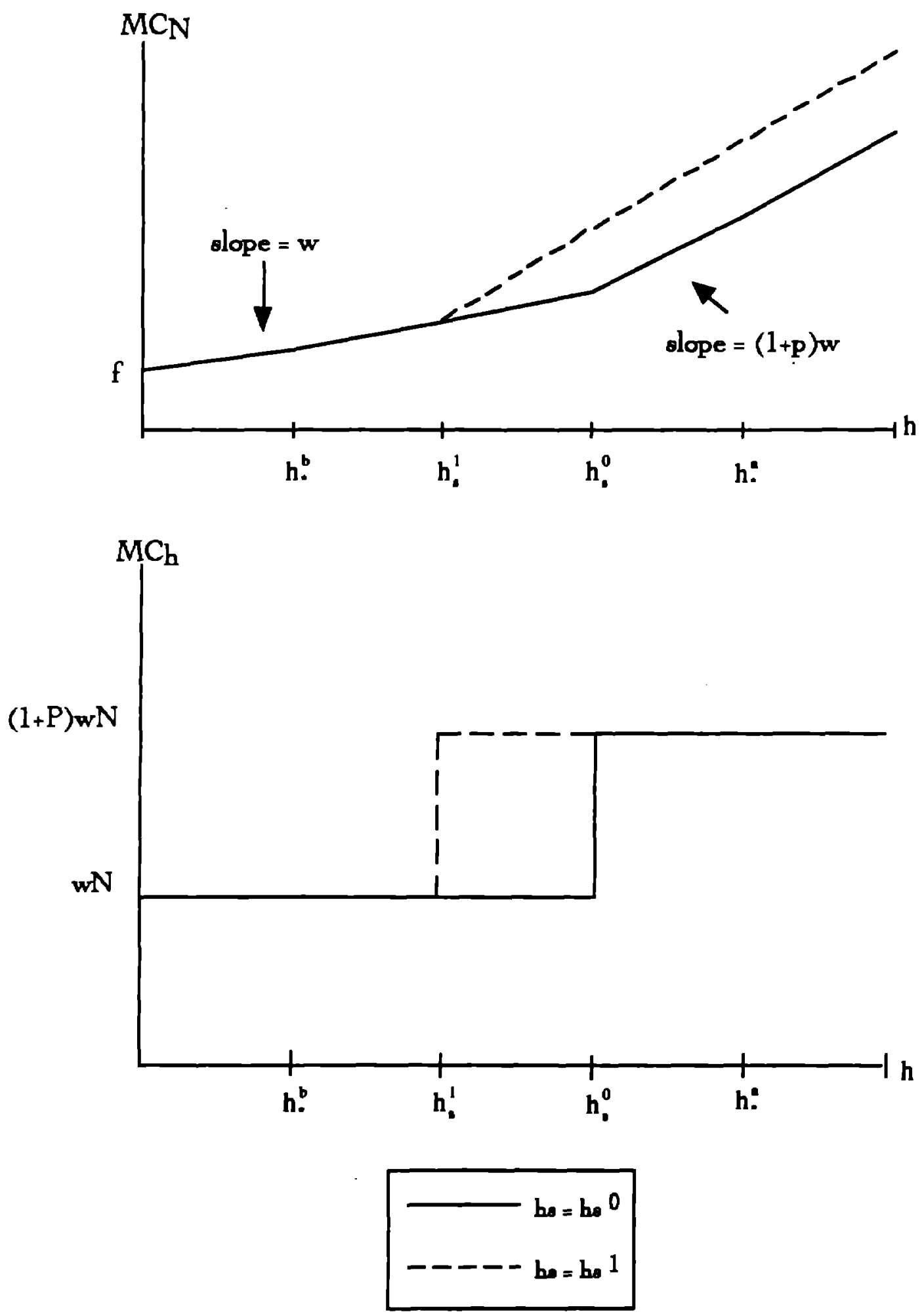

Figure 1a 

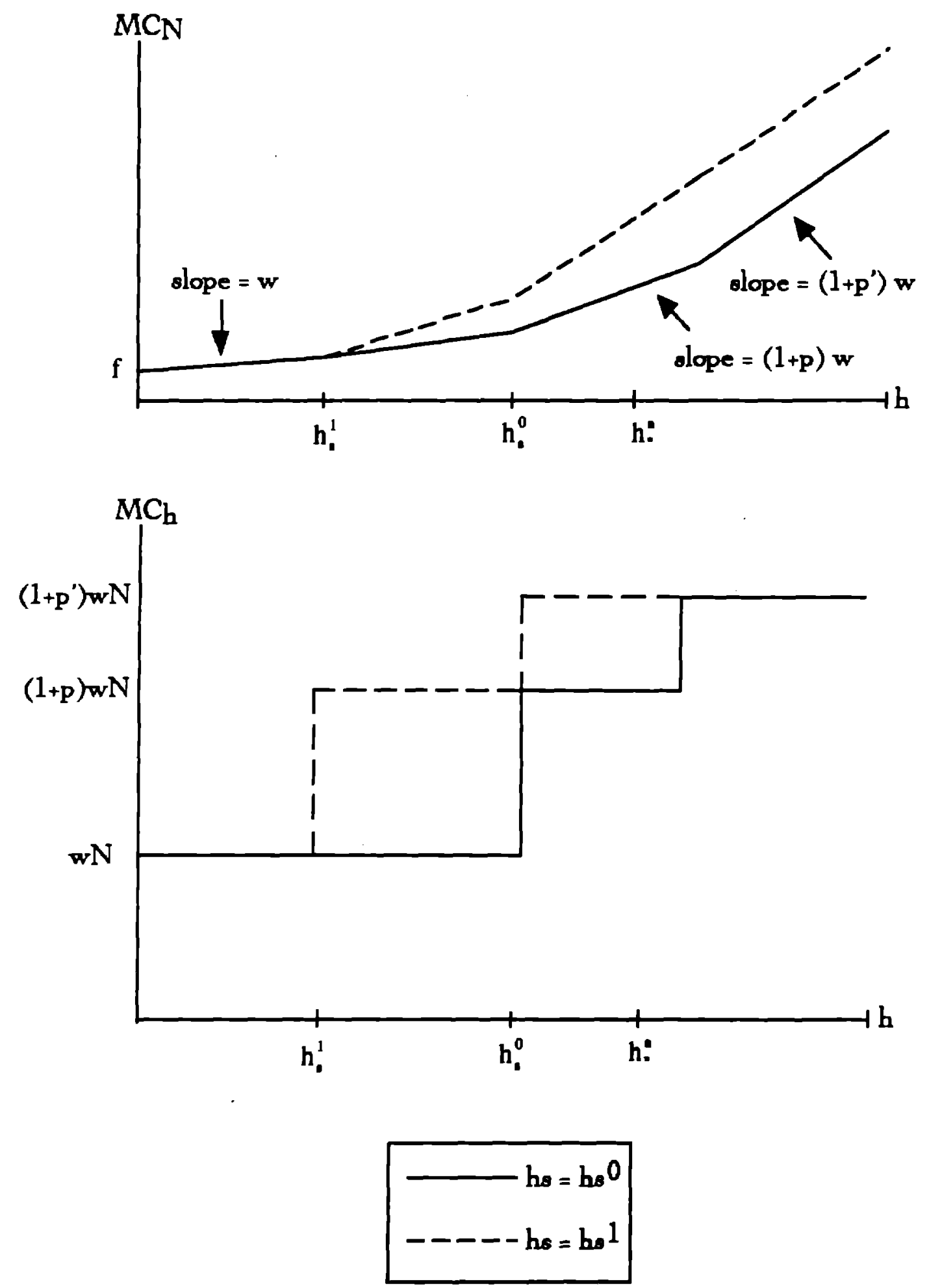

Figure 1b 


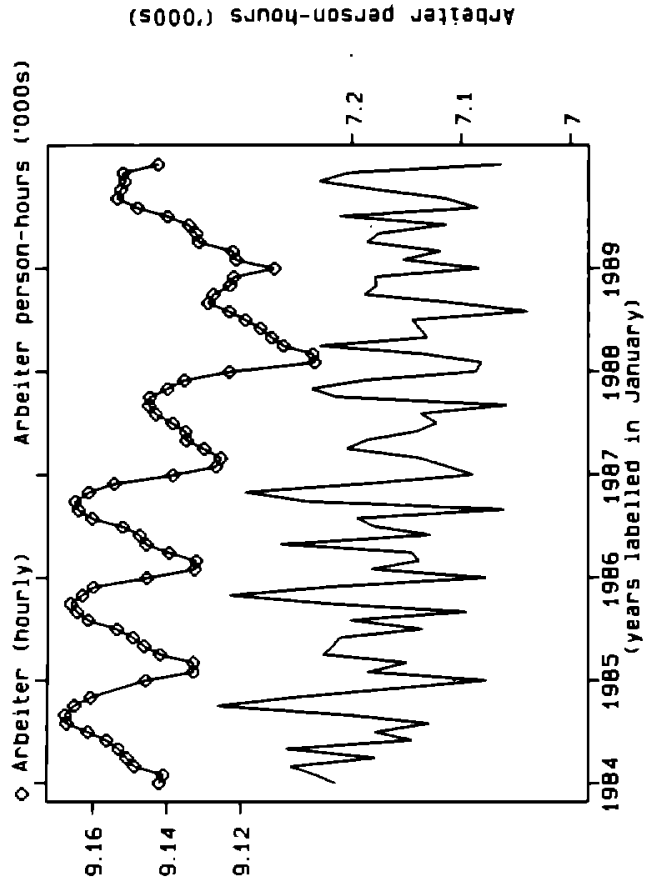

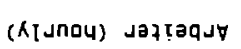

sunou puepuezs

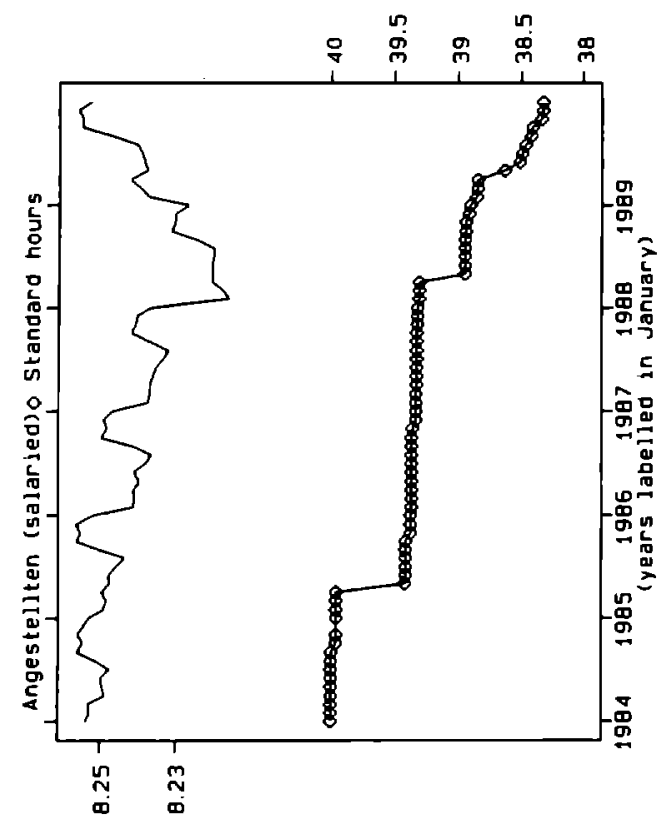

(Datjeles) valtiatsabur
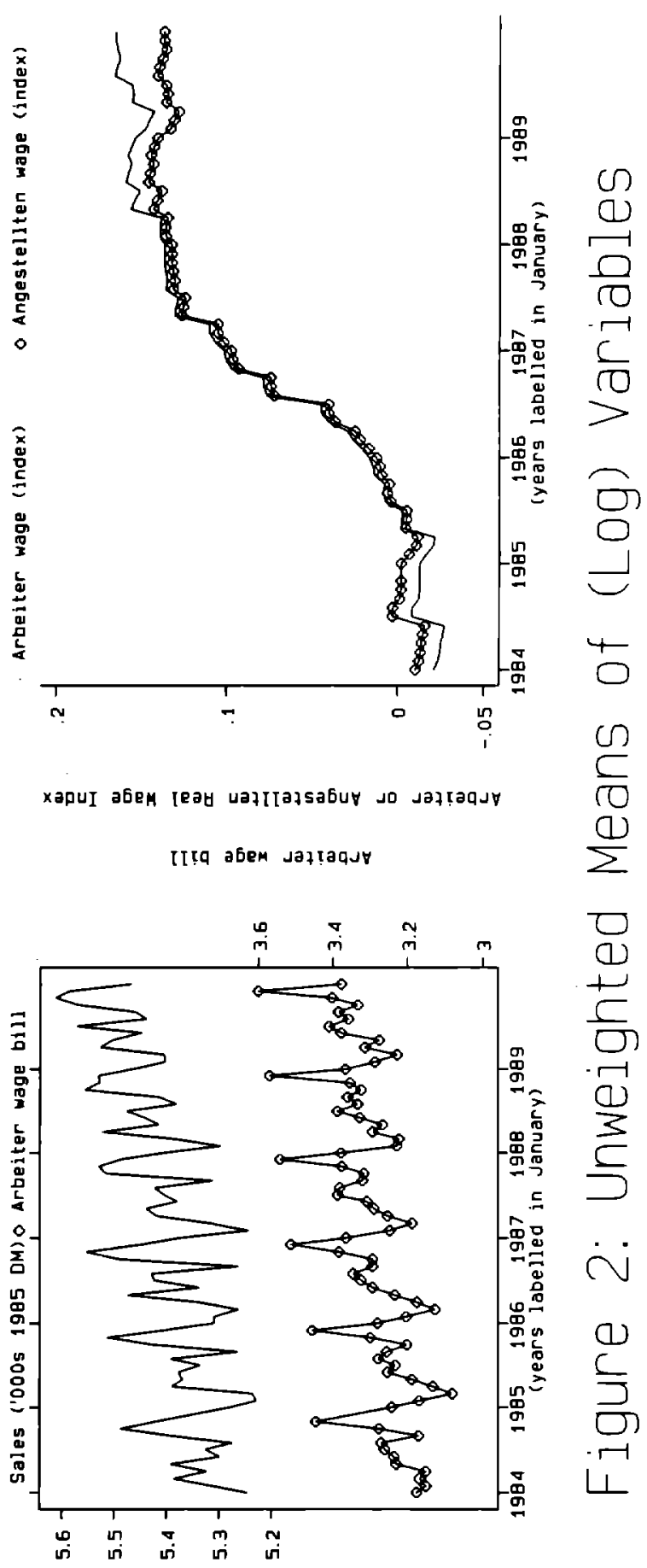

(ho 586I to spuesnout)60I SaIes lo anteA 


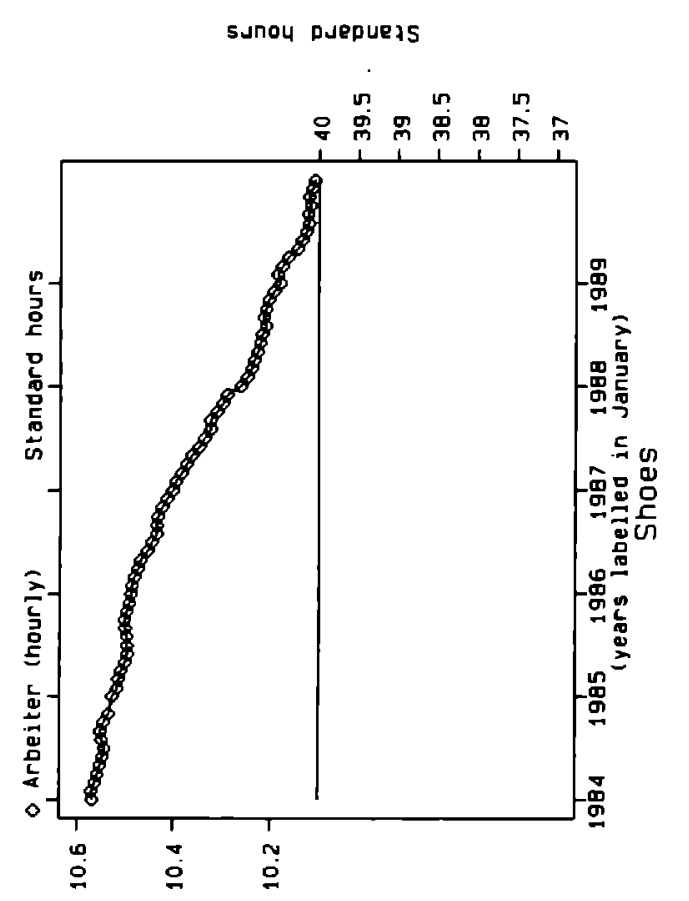

(

5unOL puepuezs

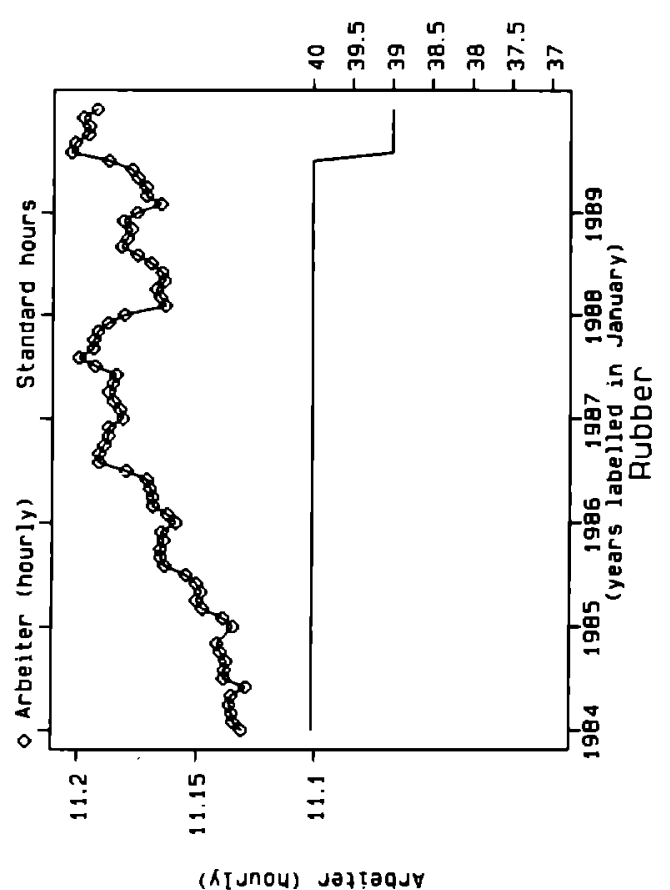

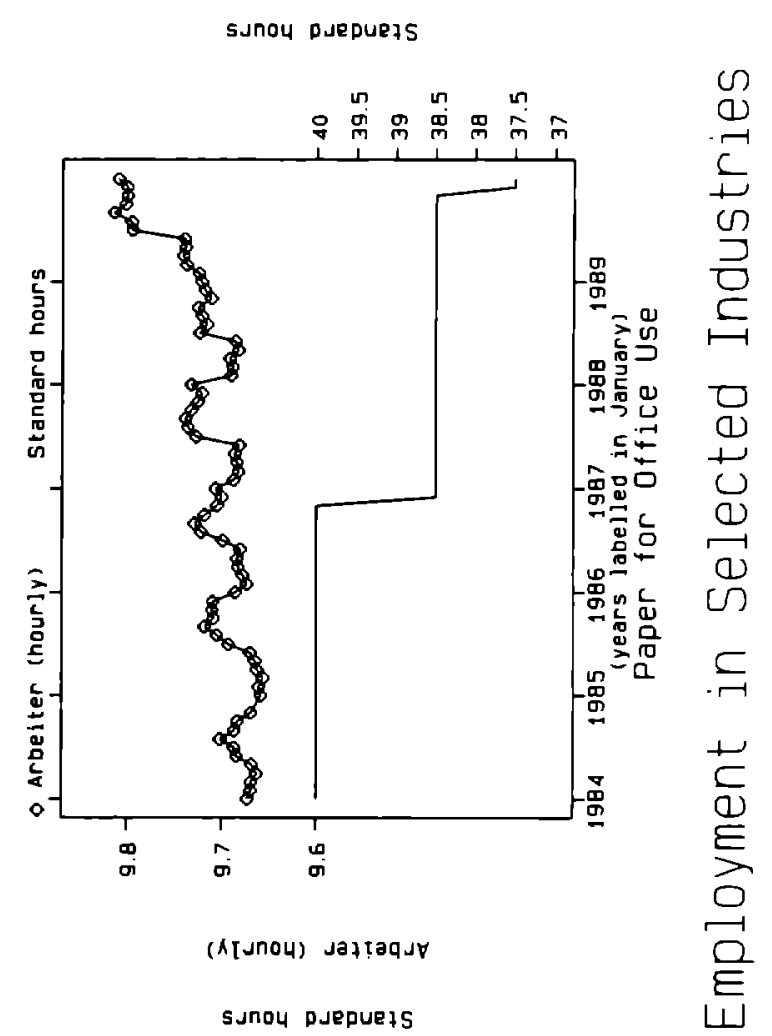

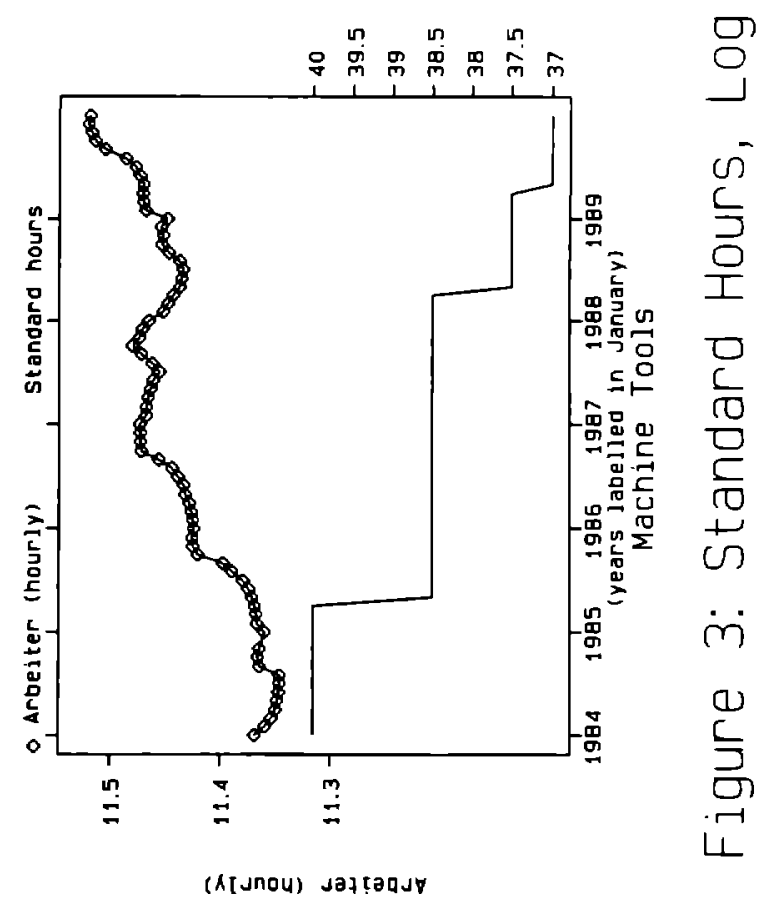



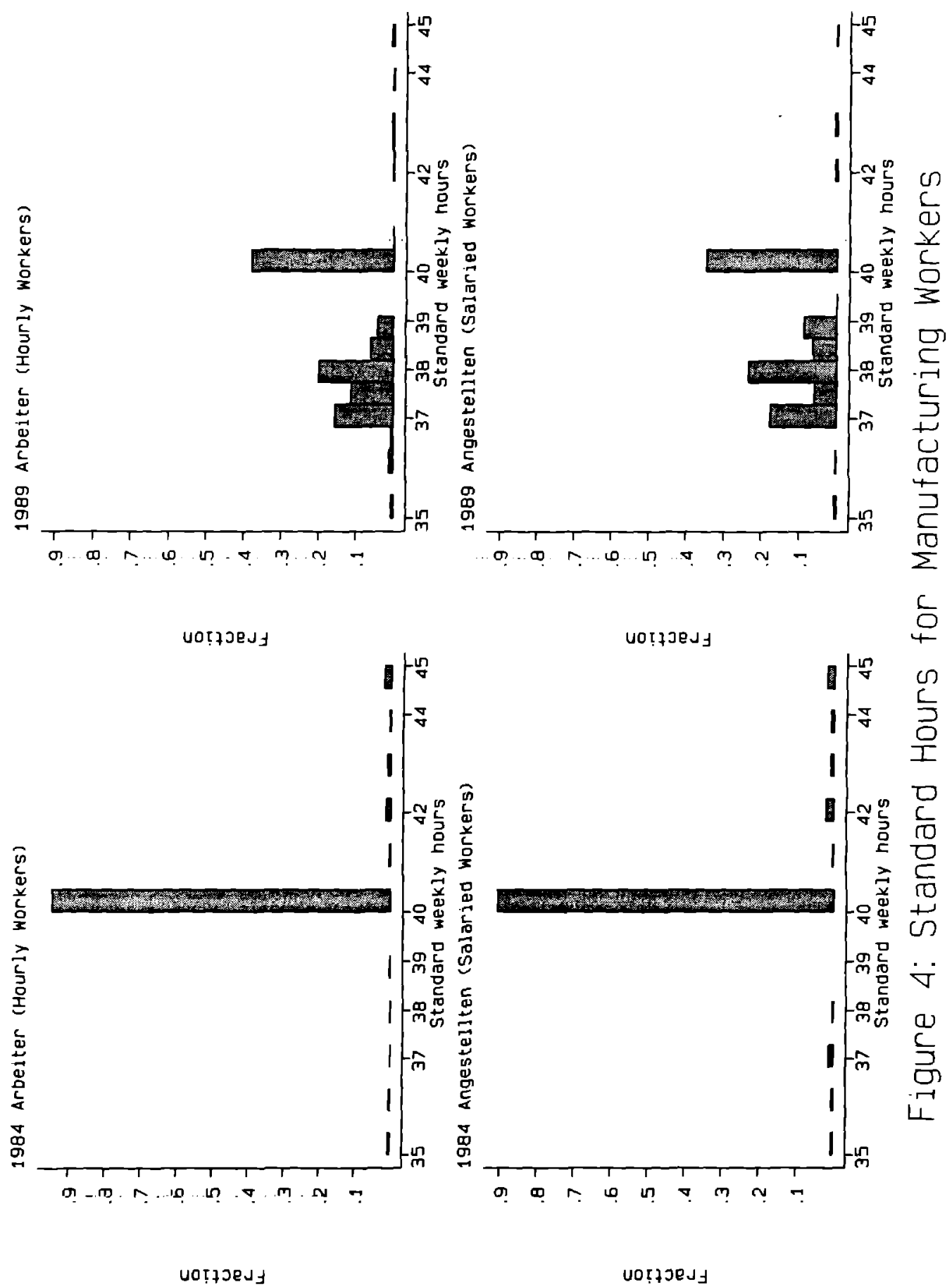